\title{
Biomass and Nutrient Accumulation of Cover Crops in the Crop Off-season in Cerrado, in Goiás State, Brazil
}

\author{
Leandro Pereira Pacheco ${ }^{1}$, Marinete Martins de Sousa Monteiro ${ }^{2}$, Rodrigo Fonseca da Silva ${ }^{3}$, Leandro dos \\ Santos Soares ${ }^{3}$, Wéverson Lima Fonseca ${ }^{3}$, Fabiano André Petter ${ }^{1}$, Francisco de Alcântara Neto ${ }^{1}$, Fernandes \\ Antônio de Almeida $^{1}$ \& Glenio Guimarães Santos ${ }^{4}$ \\ ${ }^{1}$ Department of Agronomy, Plant Science of Federal University of Piauí, Bom Jesus, PI, Brazil \\ ${ }^{2}$ Student of Pos-Graduate Program in Agronomy, Plant Science of Federal University of Piauí, Bom Jesus, PI, Brazil \\ ${ }^{3}$ Student Graduate Program in Agronomy, Federal University of Piauí, Bom Jesus, PI, Brazil \\ ${ }^{4}$ Department of Agronomy, Soil Science of Federal University of Piauí, Bom Jesus, PI, Brazil \\ Correspondence: Leandro Pereira Pacheco, Pos-Graduate Program in Agronomy-Plant Science, Federal \\ University of Piauí, Bom Jesus, PI, 64900-000, Brazil. Tel: 55-89-9997-0577. E-mail: \\ leandroppacheco@terra.com.br
}

Received: May 31, 2012 Accepted: June 19, 2012 Online Published: August 8, 2012

doi:10.5539/jas.v4n9p209 URL: http://dx.doi.org/10.5539/jas.v4n9p209

\begin{abstract}
The objective of this work was to evaluate the performance of cover crops as for biomass production and nutrient accumulation during the crop off-season in an oxisol in Cerrado, in Goiás State, Brazil. The experiment was performed in Rio Verde, GO, Brazil, from November, 2007 to October, 2008. It was used a randomized block design, with plots divided according to time, with cover crops, and subplots, concerning biomass sampling, with four repetitions. The evaluated cover crops were: Brachiaria ruziziensis, Pennisetum glaucum and B. ruziziensis + Cajanus cajan, and as a reference, fallow treatment with sponteneous species. The biomass samples were collected five times, since the desiccation date of $P$. glaucum, 60 days after cover crop sowing, which occurred on June, $12^{\text {th }}$, 2008. The P. glaucum has shown the greatest amount of biomass and nutrient accumulation at 60 days after sowing, while the B. brizantha, B. ruziziensis and B. ruziziensis $+C$. cajan have shown significant accumulation in the end of the crop off-season.
\end{abstract}

Keywords: vegetation cover, Brachiaria, millet, decomposition, no-tillage

\section{Introduction}

The Cerrado, in Goiás States tands outs for grain production in Brazil, presenting topographic and climatic conditions that favor the development of annual crops, such as soybeans, corn, cotton and rice. During 2011/12 crop season, areas for the cultivation of grain in the state reached 4.5 million hectares, producing 18.3 million tonnes, representing $8.3 \%$ and $11.4 \%$ of the total cultivated area and production amount of Brazil [National Company Supply (CONAB, 2012)], respectively. No-tillage systems are recommended to minimize environmental impacts on agricultural production systems, causing soil disturbance just in the row, using crop rotation (Crusciol et al., 2005) and leaving biomass on the soil surface for the sowing of the next crop (Bertin, Andrioli, \& Centurion, 2005). Studies have shown that this system viability is related to the quality and quantity of mulch produced by cover crops and its capacity of persistence on the soil surface (Nunes et al., 2006; Pires et al., 2008; Fabian, 2009).

Cover crops are used in order to reduce erosion and to increase soil organic matter (Prior, Torbert, Runion \& Rogers, 2004), besides providing nutrient cycling after the annual crop harvesting (Aita \& Giacomini, 2003; Boer et al., 2007; Torres \& Pereira, 2008). Some species have been recommended for the Cerrado, such as Pennisetum glaucum (pearl millet), which presents rapid growth, high biomass production and the ability to cycle nutrients, being a specie that even in conditions of water deficit has been widely used (Pacheco et al., 2011). To have cover specie which is effective in nutrient cycling there should be synchronization between the nutrient released by the cover crop mulch and the demand of the commercial culture of interest, grown in sequence (Braz, Silveira, Kliemann, \& Zimmermann, 2004). According to Crusciol \& Soratto (2009), P. glaucum is a specie which has a high ability to extract nutrients, especially nitrogen and potassium. Boer et al. (2007) 
have found that in the Cerrado, in Goiás State, Brazil, the cultivar ADR 300, sowned in April, has obtained the flowering stage at 60 days after emergence, with dry biomass production exceeding $10000 \mathrm{~kg} \mathrm{ha}^{-1}$.

Brachiaria species if compared to P. glaucum have slow initial growth, but after it starts to rain, in September/October, its potential to accumulate significantly amount of dry biomass and nutrients increases (Pacheco et al., 2011). According to Giancotti et al. (2010), Brachiaria ruziziensis presents adequate characteristics to soil covering, such as significant growth of aerial parts and roots, besides tolerance to water stress conditions. In studies performed by Amabile, Fancelli \& Carvalho (2000), it was possible to observe that intercropping of Brachiaria species of the genus Urochloa with legumes such as Cajanus cajan (pigeon pea), could mean an increase of biomass and soil nitrogen biological fixation (Henriksen, Michelson \& Schlonvoigt, 2002). Torres, Pereira, Andrioli, Polidoro \& Fabian (2005) have observed that Cajanus cajan obtained $62 \mathrm{~kg} \mathrm{ha}^{-1}$ of nitrogen in its biomass at 110 days after sowing in the off-season. Gama-Rodrigues, Gama-Rodrigues \& Brito (2007) have shown that the introduction of leguminous as cover crops has increased the quality of mulch, due to the higher supply of nitrogen, phosphorus and calcium to soil.

Although some studies have been conducted with the use of cover crops in the off-season, after harvest of annual crops, it is still necessary to perform a study to identify the species that have potential to develop on water deficit conditions, with significant biomass production. Moreover, the ability of cover crops to promote nutrient cycling may represent an increase in the adoption of no-tillage system, since the high cost of chemical fertilizers has favored the development of techniques that can promote greater efficiency as for the use of soil nutrients. The objective of this study was to evaluate the performance of cover crops as for the production of biomass and nutrient accumulation during the crop off-season in an Oxisol in Cerrado, in Goiás State, Brazil.

\section{Materials and Methods}

\subsection{Area Descriptions}

The experiment was conducted in Rio Verde, Goiás, Brazil, at the Technological Center of COMIGO $\left(17^{\circ} 47^{\prime} 30\right.$ "S, 50 57'44" W and altitude $770 \mathrm{~m}$ ) from December, 2007 to October, 2008 in an Oxisol (Embrapa, 1999), with the following characteristics as for $0-20 \mathrm{~cm}$ layer: $420,110,470 \mathrm{~g} \mathrm{~kg}^{-1}$ clay, silt and sand, respectively, $\mathrm{pH}$ $\left(\mathrm{CaCl}_{2}\right)$ 4.8, $4.2 \mathrm{mg} \mathrm{kg}^{-1} \mathrm{P}$ (Mehlich 1), $0.14 \mathrm{cmolc} \mathrm{dm}^{-3} \mathrm{~K}, 1.9 \mathrm{cmol}_{\mathrm{c}} \mathrm{dm}^{-3} \mathrm{Ca}, 0.4 \mathrm{cmol}_{\mathrm{c}} \mathrm{dm}^{-3} \mathrm{Mg}, 4.7 \mathrm{cmol}_{\mathrm{c}} \mathrm{dm}^{-3}$ $\mathrm{H}+\mathrm{Al}, 29.0 \mathrm{~g} \mathrm{~kg}^{-1}$ organic matter, $7.1 \mathrm{cmol}_{\mathrm{c}} \mathrm{dm}^{-3}$ cation exchange capacity (CEC) and $32 \%$ of saturation of base (V).

In previous crop seasons (2005/06 and 2006/07), the area was planted with soybeans and millet in crop off-season, in a no-tillage system. The study location climate, according to Köppen classification is Cwa. The precipitation that was observed during the experiment is shown in Figure 1.
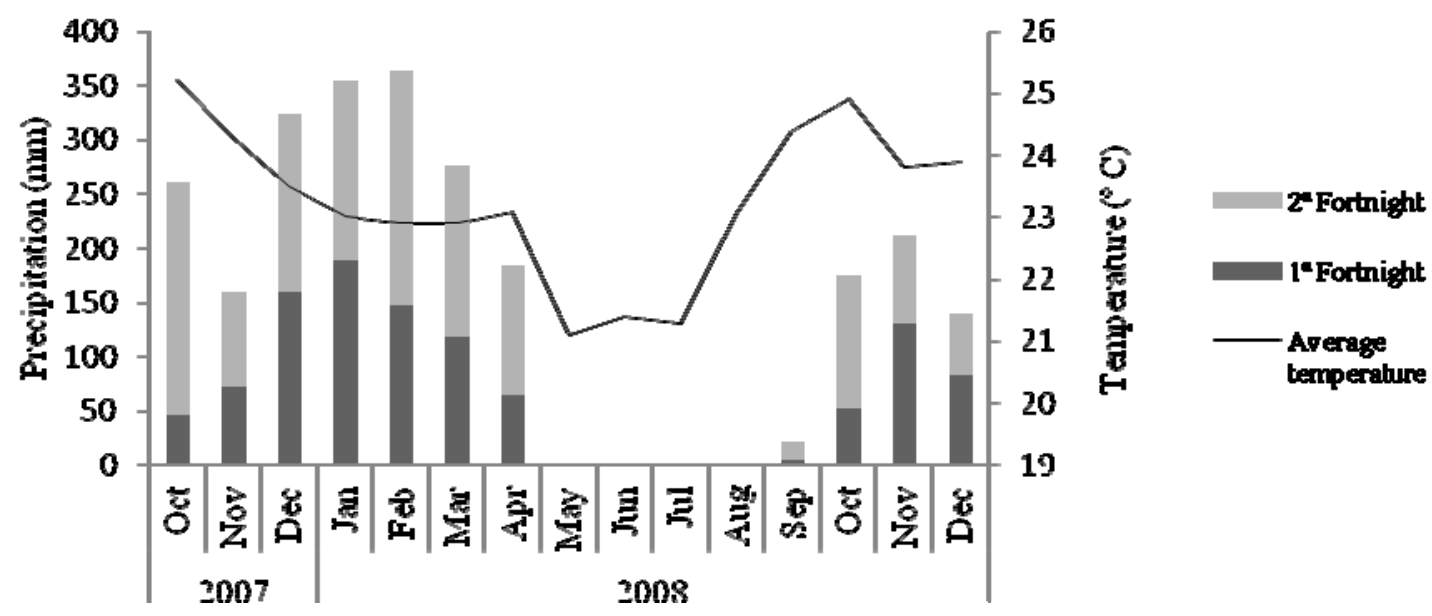

Figure 1. Precipitation and average temperature in Rio Verde, Goiás, Brazil, during the experiment

\subsection{Statistical Design and Treatments}

The soybean harvest in 2007/08 occurred on April 9, and on April 10, 2008 cover crops seedlings were sown in a 
randomized blocks design, in a split-splot array $(4 \times 5 \mathrm{~m})$, with four replications. The plots consisted of three species of cover crops and fallow: Brachiaria ruziziensis $\left(10 \mathrm{~kg} \mathrm{ha}^{-1}\right.$ seed), Pennisetum glaucum (millet ADR $300-13 \mathrm{~kg} \mathrm{ha}^{-1}$ ), Brachiaria ruziziensis + Cajanus cajan (pigeon pea, $5 \mathrm{~kg} \mathrm{ha}^{-1}+10 \mathrm{~kg} \mathrm{ha}^{-1}$ respectively) and fallow (weed, with a predominance of spiderwort - Commelina benghalensis, bulva - Conyza bonariensis and beggarticks - Bidens pilosa). The plots were tested with cover crops, which were sown handly, with a $50 \mathrm{~cm}$ sowing line space, without the use of fertilizers. The area of each plot consisted of $(5 \mathrm{~m} \times 10 \mathrm{~m})$. As for the subplots, five sampling periods of biomass were evaluated: 0, 15, 30, 60 and 120 days from the date of desiccation of Pennisetum glaucum at the time of flowering stage, which occurred on June, 12, 2008, corresponding to $60,75,90,120$ and 180 days after cover crops sowing.

\subsection{Variables and Methods}

Cover crops dry matter was evaluated in all subplots, according to the methodology proposed by Crusciol et al. (2005), using an iron square $\left(0.25 \mathrm{~m}^{2}\right)$, with two replicates per subplot. Then, matter was dried in a forced circulation oven and weighed to obtain the amount of dry biomass. These residues were triturated in Willey type mill (2 mm mesh) for subsequent determination of total nitrogen $(\mathrm{N})$, phosphorus $(\mathrm{P})$, potassium $(\mathrm{K})$, calcium (Ca) and magnesium $(\mathrm{Mg})$, following the methodology proposed by Nogueira et al. (2005). To determine the $\mathrm{C} / \mathrm{N}$ ratio, the concentration of total carbon in plant tissues was quantified by colorimetric method (Cantarella, Quaggio \& Raij, 2001).

The soil coverage rate was obtained using an iron square $0.5 \times 0.5 \mathrm{~m}\left(0.25 \mathrm{~m}^{2}\right)$ with a network of $5 \mathrm{~cm}$ spaced, ten-point form, in which it was possible to note the presence or absence of coverage provided by residues in each of these points (Sodré Filho, Cardoso, Carmoral \& Carvalho, 2004).

To describe the decomposition of biomass and cover crops nutrient release, after P. glaucum desiccation, the data were fitted into an exponential mathematical model, described by Wieder and Lang (1982), PL = Po exp (-kt) and $\mathrm{PL}=\mathrm{Co}+\mathrm{Po} \exp (-\mathrm{kt})$, in which, $\mathrm{PL}$ is the amount of biomass and nutrientsduring time $\mathrm{t}\left(\mathrm{kg} \mathrm{h}^{-1}\right)$, Co is an adjustment constant of the model and Po is the fraction of biomass and nutrients potentially released $\left(\mathrm{kg} \mathrm{ha}^{-1}\right) ; \mathrm{k}$ is the nutrient released rate $\left(\mathrm{g} \mathrm{g}^{-1}\right)$. With the value of $\mathrm{k}$, we have calculated the half-life $(\mathrm{t} 1 / 2$ life $)$ of biomass and remaining nutrients, using the formula $t 1 / 2$ life $=0.693 / \mathrm{k}$, proposed by Paul and Clark (1989). To describe the accumulation of biomass and nutrients by cover crops, a linear polynomial equation was used: $P a=P o+a x$, in which $P a$ is the amount of biomass and nutrients in time $x\left(\mathrm{~kg} \mathrm{ha}^{-1}\right), a$ the daily accumulation rate of dry biomass and nutrients $\left(\mathrm{kg} \mathrm{day}^{-1}\right)$.

\subsection{Statistical Analysis}

The results were subjected to variance analysis, and, the averages, compared by Tukey test at 5\% probability. The regression equations were obtained using the software Sigma Plot, version 10.0.

\section{Results and Discussion}

The cover crops have presented significant effects as for biomass production, soil covering and nutrient accumulation at different sampling times (Table 1). Concerning the production of biomass (DB) and the rate of soil covering (SC) at $60 \mathrm{DAS}$, it was possible to verify higher values for P. glaucum (Table 2), due to the rapid growth and high production of DB (more than $3000 \mathrm{~kg} \mathrm{ha}^{-1}$ ) at the early flowering stage. This value was lower than those found by (Boer et al., 2007) and (Pacheco et al., 2008), who have found $10100 \mathrm{~kg} \mathrm{ha}^{-1}$ and $8700 \mathrm{~kg}$ $\mathrm{ha}^{-1}$, respectively. The low production of DB in this work was related to late sowing and low water availability (Figure 1), what have difficulted the development of cover crops. These results demonstrate that this species requires water availability for its initial development, what appears to be crucial to its survival under conditions of water deficit during the off-season

Table 1. Variance analysis ( $\mathrm{F}$ value) for biomass, soil covering rate, carbon/nitrogen ratio and nutrients accumulation and releasing, crop season 2007/2008 in Rio Verde, GO, Brazil

\begin{tabular}{lllllllll}
\hline $\begin{array}{l}\text { Source of } \\
\text { variation }\end{array}$ & Biomass & $\mathrm{SC}^{(1)}$ & $\mathrm{C} / \mathrm{N}^{(2)}$ & $\mathrm{N}$ & $\mathrm{P}$ & $\mathrm{K}$ & $\mathrm{Ca}$ & $\mathrm{Mg}$ \\
\hline Cover crops & $7.33^{* *}$ & $18.16^{* *}$ & $15.01^{* *}$ & $16.60^{* *}$ & $6.06^{* *}$ & $10.27^{* *}$ & $38.34^{* *}$ & $27.26^{* *}$ \\
Sampling times & $47.09^{* *}$ & $0.49^{\text {ns }}$ & $22.88^{* *}$ & $6.88^{* *}$ & $10.16^{* *}$ & $22.05^{* *}$ & $114.47^{* *}$ & $66.05^{* *}$ \\
$\mathrm{C} \mathrm{C}^{(3)} \mathrm{PS}^{(4)}$ & $18.06^{* *}$ & $3.19^{* *}$ & $2.11^{*}$ & $11.06^{* *}$ & $11.28^{* *}$ & $26.44^{* *}$ & $20.26^{* *}$ & $25.75^{* *}$ \\
\hline
\end{tabular}

(N) Not significant $\mathrm{F}^{*}$ and ${ }^{* *}$ Significant at 5 and $1 \%$ probability level, ${ }^{(1)}$ Rate of soil coverage, ${ }^{(2)}$ Carbon / Nitrogen Ratio, ${ }^{(3)}$ Cover Crops, ${ }^{(4)}$ Sampling times. 
From 120 DAS on, cover crops U. ruziziensis and U. ruziziensis ruziziensis $+C$. cajan have adquired highlight as for the production of DB in no-tillage system, exceeding the millet residues left by its desiccation at 60 DAS, which resulted in a higher SC. These results can be certified by a linear increasing DB concerning the accumulation of these species during the off-season (Table 2). At the end of the off-season, tolerance to drought and regrowth of the species U. ruziziensis after the resumption of rains have contributed to the increase of SC and DB.

At 180 DAS, U. ruziziensis grown single and in consortium had similar production in both systems, approximately $5000 \mathrm{~kg} \mathrm{ha}^{-1}$ of DB (Table 2). These results corroborate with Pacheco et al. (2011), Pacheco et al. (2008) and Torres, Pereira, Andrioli, Polidoro \& Fabian (2005), who have found similar values in Cerrado region (4 $908 \mathrm{~kg} \mathrm{ha}^{-1}, 5400 \mathrm{~kg} \mathrm{ha}^{-1}$ and $6000 \mathrm{~kg} \mathrm{ha}^{-1}$ respectively), but differ from Menezes \& Leandro (2004), who have observed $6893 \mathrm{~kg} \mathrm{ha}^{-1}$ at 180 DAS. It was possible to observe that as for the consortium U. ruziziensis $+C$. cajan, the $U$. ruziziensis, the first has presented major contribution to DB production, what reinforces the low efficiency of leguminous species in off-season, due to the deleterious effects of water stress on initial growth of these species.

At the end of the off-season, beginning of precipitation, the fallow area has presented a higher DB if compared to the P. glaucum residues (Table 2). However, these DB quantities are insufficient to the development of a soil conservation management. Menezes et al. (2009) have observed that it is necessary at least $12 \mathrm{~kg} \mathrm{ha}^{-1} \mathrm{DB}$ to maintain a fair amount of soil surface covering throughout the growing season. The adoption of the use of fallow hasnot been recommended in Cerrado region due to the difficulty for weed management during the growth of annual crops (Pires et al., 2008).

Table 2. Biomass and cover crops soil covering rate (Urochloa ruziziensis, Pennisetum glaucum and U. ruziziensis + Cajanus cajan) and fallow, sowned after the soybean harvest in crop season 2008/2009 and evaluated during five periods in Rio Verde, GO, Brazil ${ }^{(1)}$

\begin{tabular}{|c|c|c|c|c|c|c|c|}
\hline \multirow{2}{*}{ Cover Crops } & \multicolumn{5}{|c|}{$\mathrm{DAS}^{(2)}$} & \multirow[t]{2}{*}{ Equation } & \multirow[t]{2}{*}{$\mathbf{R}^{2}$} \\
\hline & 60 & 75 & 90 & 120 & 180 & & \\
\hline \multicolumn{8}{|c|}{ Biomass $\left(\mathrm{kg} \mathrm{ha}^{-1}\right)$} \\
\hline $\mathrm{UR}^{(3)}$ & $1.190 \mathrm{~b}$ & $2.033 \mathrm{~b}$ & $2.517 \mathrm{a}$ & $2.808 \mathrm{ab}$ & $4.827 \mathrm{a}$ & $(\mathrm{Y}=1415,7500+27,9833 * \mathrm{x})^{* *}$ & 0,97 \\
\hline $\mathrm{PG}^{(4)}$ & $3.392 \mathrm{a}$ & $2.970 \mathrm{a}$ & $2.444 \mathrm{a}$ & $2.277 \mathrm{~b}$ & $2.033 \mathrm{c}$ & $\left(\mathrm{Y}=2014,5206+1397,3806 * \exp (-0,0317 * \mathrm{x})^{* *}\right.$ & 0,98 \\
\hline $\mathrm{UR}+\mathrm{CC}^{(5)}$ & $828 \mathrm{~b}$ & $2.237 \mathrm{ab}$ & $2.760 \mathrm{a}$ & $3.342 \mathrm{a}$ & $4.833 \mathrm{a}$ & $(\mathrm{Y}=1465,8250+29,6483 * \mathrm{x})^{* *}$ & 0,92 \\
\hline $\mathrm{P}^{(6)}$ & $1.051 \mathrm{~b}$ & $1.941 \mathrm{~b}$ & $2.430 \mathrm{a}$ & $2.499 \mathrm{~b}$ & $3.035 \mathrm{~b}$ & $\left(\mathrm{Y}=1575,5250+13,6817^{*} \mathrm{x}\right)^{*}$ & 0,94 \\
\hline CV $(\%)$ & 17,00 & & & & & & \\
\hline \multicolumn{8}{|c|}{ Rate of soil coverage ( $\%)$} \\
\hline UR & 86,2 a & 86,3 a & $86,3 \mathrm{a}$ & $80,6 \mathrm{a}$ & $100,0 \mathrm{a}$ & $(\mathrm{Y}=83,1475+0,1052 * \mathrm{x}) \mathrm{ns}$ & 0,48 \\
\hline PG & $73,7 \mathrm{a}$ & $73,8 \mathrm{a}$ & $73,8 \mathrm{a}$ & $75,0 \mathrm{a}$ & $60,0 \mathrm{~b}$ & $\left(\mathrm{Y}=76,3225+(-0,1125)^{*} \mathrm{x}\right) \mathrm{ns}$ & 0,71 \\
\hline $\mathrm{UR}+\mathrm{CC}$ & $82,5 \mathrm{a}$ & $82,5 \mathrm{a}$ & $82,5 \mathrm{a}$ & $76,9 \mathrm{a}$ & $95,0 \mathrm{a}$ & $(\mathrm{Y}=79,6125+0,0948 * \mathrm{x}) \mathrm{ns}$ & 0,45 \\
\hline $\mathrm{P}$ & $76,2 \mathrm{a}$ & $76,3 \mathrm{a}$ & $76,3 \mathrm{a}$ & 83,1 a & $73,7 \mathrm{~b}$ & $(\mathrm{Y}=77,5625+(-0,0098) * \mathrm{x}) \mathrm{ns}$ & 0,02 \\
\hline CV (\%) & 9,63 & & & & & & \\
\hline
\end{tabular}

${ }^{(1)}$ Means followed by same letters in columns do not differ by Tukey test at 5\% probability, ${ }^{(2)}$ DAS, days after sowing of cover crops in Rio Verde, GO, 04/10/2008, ${ }^{(3)}$ U. ruzizienses, ${ }^{(4)}$ P. glaucum in flowering stage, ${ }^{(5)}$ U.ruzizienses intercropped with $C$. cajans, ${ }^{(6)}$ fallow. ${ }^{*}$ and ${ }^{* *}$ Significant at $5 \%$ and $1 \%$ probability by Tukey test $^{\text {ns }}$ - not significant.

It was found that the highest $\mathrm{C} / \mathrm{N}$ ratios were related to $P$. glaucum biomass (Table 3 ). This fact can be explained since this species quickly reach the stage of flowering at $60 \mathrm{DAS}$, and after desiccation management, it hasinitiated the decomposition of its residues. Boer et al. (2007) have observed that P. glaucum have provided more persistence residues concerning decomposition, what can be attributed to its cellular composition, higher levels of lignin and cellulose, organic compounds which are difficult to decompose, making it more resistant to the action of microorganisms. Carpim et al. (2008) have found different values of $\mathrm{C} / \mathrm{N}$ ratio of 18, 19 and 22:1 
for P. glaucum cultivar ADR 300 in Cerrado, in the southwestern of Goiás State, in stages of dormancy-booting and pre-flowering.

During the off-season, U. ruziziensis and the consortium U. ruziziensis + C. cajan have shown the lowest $\mathrm{C} / \mathrm{N}$ ratios due to its slow development if compared to P. glaucum and fallow at all evaluation periods (Table 3 ). The lowest $\mathrm{C} / \mathrm{N}$ ratios provided by these plants at the end of the off-season after desiccation management can provide increased rate of plant residues decomposition, with a faster release of nutrients to be used during the next harvest. In fallow, with rains onset, there is a rapid establishment and development of weeds, what have increased the soil coverage. At $120 \mathrm{DAS}$, the fallow has stood out with a higher $\mathrm{C} / \mathrm{N}$ due to heavy infestation of species of the grass family (Table 3), what corroborates the studies of Torres \& Pereira (2008), who have observed values of $\mathrm{C} / \mathrm{N}$ ratio in grasses almost three times higher than in legumes.As for nutrient accumulation in cover crops, it was observed that, at $60 \mathrm{DAS}, P$. glaucum has accumulated higher levels of $\mathrm{N}, \mathrm{K}, \mathrm{P}, \mathrm{Ca}$ and $\mathrm{Mg}$ (Table 3). This is related to a higher aerial parts biomass production, since this species quickly reaches the flowering stage. Concerning N accumulation, similar values have been found by Pacheco et al. (2011), $70 \mathrm{~kg} \mathrm{ha}^{-1}$, while Boer et al. (2007) have found values higher than $121 \mathrm{~kg} \mathrm{ha}^{-1}$. The $\mathrm{K}$ amount was lower than those reported by Carpim et al. (2008) and Torres \& Pereira (2008), with 218 and $447 \mathrm{~kg} \mathrm{ha}^{-1}$, respectively.

Regarding the nutrient accumulation by cover crops that were not desiccated in initial reproductive stage, it was observed that at $180 \mathrm{DAS}$, the nutrient accumulated in greater quantity was $\mathrm{N}$, in U. ruziziensis single and U. ruziziensis + C. cajan (Table 3). The use of leguminous C. cajan intercropped with U. ruziziensis did not make it possible to increase the $\mathrm{N}$ accumulation, if compared with the single cultivation of grass U. ruziziensis, what can be explained by the slow development of the leguminous grown on low-water regime. Moreover, the use of grass can alleviate the loss of $\mathrm{N}$ through its immobilization in biomass, besides promoting an increase in soil covering during the growth of annual crops, since these residues had higher $\mathrm{C} / \mathrm{N}$ ratio (Lara Cabezas, Alves, Urquiaga, \& Santana, 2004; Perin, Santos, Urquiaga, War, \& Cecon, 2004). The P.glaucum has shown a reduction in the $\mathrm{N}$ accumulated amount in their residues due to the decomposition of biomass after the desiccation on initial reproductive stage, what has occurred at 60 DAS (Table 3).

Table 3. Carbon/nitrogen ratio and nutrient accumulated $\left(\mathrm{kg} \mathrm{ha}^{-1}\right)$ in the biomass of cover crops sown in the second crop, after soybean harvest, 2007/2008 season, evaluated at five sampling periods during the offseason, in Rio Verde, $\mathrm{GO}^{(1)}$

\begin{tabular}{|c|c|c|c|c|c|c|c|c|}
\hline Plants & $\mathrm{DAS}^{(3)}$ & & & & & Equation & $\mathrm{T}_{1 / 2}$ & $\mathrm{R}_{2}$ \\
\hline cover & 60 & 75 & 90 & 120 & 180 & & & \\
\hline \multicolumn{9}{|c|}{ Carbon/Nitrogen Ratio } \\
\hline $\mathrm{UR}^{(2)}$ & $21 \mathrm{~b}$ & $30 \mathrm{~b}$ & $38 \mathrm{a}$ & $44 b$ & $37 \mathrm{a}$ & $(\mathrm{Y}=28,9000+0,1133 * \mathrm{x}) \mathrm{ns}$ & - & 0,37 \\
\hline PG & $38 \mathrm{a}$ & $47 \mathrm{a}$ & $46 \mathrm{a}$ & $46 \mathrm{~b}$ & $50 \mathrm{a}$ & $(\mathrm{Y}=42,2500+0,0700 * \mathrm{x}) \mathrm{ns}$ & - & 0,56 \\
\hline $\mathrm{UR}+\mathrm{CC}^{(4)}$ & $20 \mathrm{~b}$ & $30 \mathrm{~b}$ & $37 \mathrm{a}$ & $40 \mathrm{~b}$ & $38 \mathrm{a}$ & $(\mathrm{Y}=27,5250+0,1217 * \mathrm{x}) \mathrm{ns}$ & - & 0,50 \\
\hline $\mathrm{P}^{(5)}$ & $24 \mathrm{~b}$ & $35 \mathrm{ab}$ & $45 \mathrm{a}$ & $62 \mathrm{a}$ & $50 \mathrm{a}$ & $(\mathrm{Y}=33,8250+0,2083 * \mathrm{x}) \mathrm{ns}$ & - & 0,46 \\
\hline $\mathrm{CV}(\%)$ & 18,38 & & & & & & & \\
\hline \multicolumn{9}{|c|}{ Nitrogen $\left(\mathrm{kg} \mathrm{ha}^{-1}\right)$} \\
\hline UR & $37,66 \mathrm{~b}$ & $49,54 \mathrm{a}$ & $48,04 \mathrm{a}$ & $44,84 \mathrm{ab}$ & $80,44 \mathrm{a}$ & $\left(\mathrm{Y}=38,0835+0,3116^{*} \mathrm{x}\right)^{*}$ & - & 0,80 \\
\hline PG & $68,44 \mathrm{a}$ & $49,88 \mathrm{a}$ & $41,03 \mathrm{a}$ & $32,45 \mathrm{bc}$ & $26,08 \mathrm{~b}$ & $\left(\mathrm{Y}=26,1773+41,8438^{*} \exp (-0,0350 * \mathrm{x})\right)^{* *}$ & 20 & 0,99 \\
\hline $\mathrm{UR}+\mathrm{CC}$ & $24,38 \mathrm{~b}$ & $50,71 \mathrm{a}$ & $55,63 \mathrm{a}$ & 60,09 a & $75,84 \mathrm{a}$ & $\left(\mathrm{Y}=37,6475+0,3485^{*} \mathrm{x}\right)^{*}$ & - & 0,80 \\
\hline $\mathrm{P}$ & $26,52 \mathrm{~b}$ & $38,80 \mathrm{a}$ & $39,88 \mathrm{a}$ & $26,18 \mathrm{c}$ & $39,61 \mathrm{~b}$ & $(\mathrm{Y}=32,1588+0,0453 * \mathrm{x}) \mathrm{ns}$ & - & 0,09 \\
\hline $\mathrm{CV}(\%)$ & 21,25 & & & & & & & \\
\hline \multicolumn{9}{|c|}{ Potassium $\left(\mathrm{kg} \mathrm{ha}^{-1}\right)$} \\
\hline UR & $21,54 \mathrm{~b}$ & $33,30 \mathrm{ab}$ & $37,35 \mathrm{a}$ & $39,53 \mathrm{a}$ & $62,67 \mathrm{a}$ & $(\mathrm{Y}=25,0547+0,3072 * \mathrm{x})^{* *}$ & - & 0.94 \\
\hline PG & $51,12 \mathrm{a}$ & $42,27 \mathrm{a}$ & 34,62 a & $27,51 \mathrm{~b}$ & $18,82 \mathrm{c}$ & $(\mathrm{Y}=15,5538+35,4501 * \exp (-0,0193 * \mathrm{x}))^{* *}$ & 36 & 0,99 \\
\hline $\mathrm{UR}+\mathrm{CC}$ & $13,27 \mathrm{~b}$ & $37,85 \mathrm{ab}$ & 39,31 a & $43,51 \mathrm{a}$ & $58,75 \mathrm{a}$ & $(\mathrm{Y}=24,8550+0,3041 * \mathrm{x})^{*}$ & - & 0,77 \\
\hline $\mathrm{P}$ & $17,25 \mathrm{~b}$ & $31,13 \mathrm{~b}$ & $30,97 \mathrm{a}$ & $41,91 \mathrm{a}$ & $32,02 \mathrm{~b}$ & $(\mathrm{Y}=26,3787+0,0951 * \mathrm{x}) \mathrm{ns}$ & - & 0,26 \\
\hline $\mathrm{CV}(\%)$ & 15,00 & & & & & & & \\
\hline \multicolumn{9}{|c|}{ Phosphorus $\left(\mathrm{kg} \mathrm{ha}^{-1}\right)$} \\
\hline UR & $3,97 \mathrm{~b}$ & $6,05 \mathrm{a}$ & $6,00 \mathrm{a}$ & $4,04 \mathrm{ab}$ & $7,41 \mathrm{a}$ & $\left(\mathrm{Y}=4,6630+0,0185^{*} \mathrm{x}\right) \mathrm{ns}$ & - & 0,35 \\
\hline PG & 9,93 a & $7,96 \mathrm{a}$ & $6,31 \mathrm{a}$ & $5,48 \mathrm{ab}$ & $3,36 \mathrm{~b}$ & $(\mathrm{Y}=2,8927+6,9117 * \exp (-0,0199 * \mathrm{x}) * *$ & 35 & 0,98 \\
\hline $\mathrm{UR}+\mathrm{CC}$ & $2,79 \mathrm{~b}$ & $7,30 \mathrm{a}$ & $6,26 \mathrm{a}$ & $5,93 \mathrm{a}$ & $8,50 \mathrm{a}$ & $(\mathrm{Y}=4,7160+0,0320 * \mathrm{x}) \mathrm{ns}$ & - & 0,51 \\
\hline $\mathrm{P}$ & $3,52 \mathrm{~b}$ & $7,22 \mathrm{a}$ & $6,58 \mathrm{a}$ & $3,67 \mathrm{~b}$ & $4,67 \mathrm{~b}$ & $(\mathrm{Y}=5,4740+(-0,0076) * \mathrm{x}) \mathrm{ns}$ & - & 0,04 \\
\hline
\end{tabular}




\begin{tabular}{|c|c|c|c|c|c|c|c|c|}
\hline CV $(\%)$ & 20,47 & & & & & & & \\
\hline \multicolumn{9}{|c|}{ Calcium $\left(\mathrm{kg} \mathrm{ha}^{-1}\right)$} \\
\hline UR & $8,44 \mathrm{~b}$ & $18,05 \mathrm{ab}$ & $16,70 \mathrm{ab}$ & $26,34 \mathrm{a}$ & 53,66 a & $(\mathrm{Y}=8,3990+0,3609 * \mathrm{x})^{* *}$ & - & 0,96 \\
\hline PG & $23,74 \mathrm{a}$ & $20,77 \mathrm{ab}$ & $12,26 \mathrm{~b}$ & $13,75 \mathrm{~b}$ & $18,30 \mathrm{c}$ & $\left(\mathrm{Y}=15,1678+9,0217 * \exp \left(-0,0753^{*} \mathrm{x}\right)\right) \mathrm{ns}$ & 9 & 0,62 \\
\hline $\mathrm{UR}+\mathrm{CC}$ & $6,93 \mathrm{~b}$ & $24,84 \mathrm{a}$ & $20,70 \mathrm{a}$ & $30,76 \mathrm{a}$ & $56,45 \mathrm{a}$ & $(\mathrm{Y}=11,2980+0,3697 * \mathrm{x})^{* *}$ & - & 0,93 \\
\hline $\mathrm{P}$ & $7,36 \mathrm{~b}$ & $15,84 \mathrm{~b}$ & $9,56 \mathrm{~b}$ & $14,03 \mathrm{~b}$ & $31,88 \mathrm{~b}$ & $\left(\mathrm{Y}=7,4758+0,1835^{*} \mathrm{x}\right)^{*}$ & - & 0,81 \\
\hline $\mathrm{CV}(\%)$ & & \multicolumn{7}{|c|}{ CV $(\%)$} \\
\hline \multicolumn{9}{|c|}{ Magnesium $\left(\mathrm{kg} \mathrm{ha}^{-1}\right)$} \\
\hline UR & $2,38 \mathrm{~b}$ & $3,78 \mathrm{~b}$ & $4,78 \mathrm{a}$ & $6,88 \mathrm{a}$ & $17,71 \mathrm{a}$ & $\left(\mathrm{Y}=1,4098+0,1266^{*} \mathrm{x}\right)^{* *}$ & - & 0,95 \\
\hline PG & $6,41 \mathrm{a}$ & $5,99 \mathrm{a}$ & $4,88 \mathrm{a}$ & $3,88 \mathrm{~b}$ & $3,52 \mathrm{~b}$ & $(\mathrm{Y}=3,1528+3,4227 * \exp (-0,0214 * \mathrm{x}))^{*}$ & 32 & 0,97 \\
\hline $\mathrm{UR}+\mathrm{CC}$ & $1,67 \mathrm{~b}$ & $4,47 \mathrm{ab}$ & $5,71 \mathrm{a}$ & $6,96 \mathrm{a}$ & $15,09 \mathrm{a}$ & $(\mathrm{Y}=2,0738+0,1046 * \mathrm{x})^{* *}$ & - & 0,97 \\
\hline $\mathrm{P}$ & $2,10 \mathrm{~b}$ & $3,63 \mathrm{~b}$ & $3,96 \mathrm{a}$ & $4,35 \mathrm{~b}$ & $4,48 \mathrm{~b}$ & $(\mathrm{Y}=3,0118+0,0154 * x) \mathrm{ns}$ & - & 0,58 \\
\hline $\mathrm{CV}(\%)$ & 20,82 & & & & & & & \\
\hline
\end{tabular}

(1) Means followed by same letters in columns do not differ by Tukey test at $5 \%$ probability, ${ }^{(2)}$ U. ruzizienses ${ }^{(3)}$ P. glaucum in dried flowering, ${ }^{(3)} \mathrm{DAS}$, days after sowing of cover crops in Rio Verde, GO, 10/4 / 2008, ${ }^{(4)}$ U.ruzizienses intercropped with C. cajans, ${ }^{(5)}$ fallow. *And ** significant at $5 \%$ and $1 \%$ probability level, ${ }^{\text {(ns) }}$ not significant.

There was greater nutrients accumulation and releasing present in P. glaucum on the initial reproductive stage, in which its desiccation has occurred (Table 3). Being contrary to previous studies (Boer et al., 2007; Pacheco et al., 2011), $\mathrm{K}$ has shown the lowest rate of decomposition of the nutrients studied, what can be explained by high conditions of water stress to which the plants were under during the time of desiccation in its flowering stage, with a high number of dry leaves and low $\mathrm{K}$ into cell tissues. Moreover, considering that $\mathrm{K}$ is a quite water soluble nutrient, the low soil moisture after the desiccation of P. glaucu, may have reduced its rate of decomposition.

The P. glaucum at DAS 60, together with U ruziziensis and the consortium U. ruziziensis $+C$. cajan at 180 DAS have shown high amounts of $\mathrm{P}, \mathrm{Ca}$ and $\mathrm{Mg}$ in their biomass. These accumulations are directly related to the high development of grass roots, since the root surface in contact with the soil is large, not to mention their ability to produce exudates that can promote the solubilization of nutrients in the rhizosphere region. According to Araújo, Sampaio \& Medeiros (2005), the use of cover crops that have high capacity to absorb phosphorus can contribute to the agricultural system, since the phosphorus fertilizers and soil acidity correction represent the largest part of the cost with the implementation of a crop in the Brazilian Cerrado.

The P. glaucum has shown a higher half-life $\left(\mathrm{T}_{1 / 2}\right)$ for $\mathrm{K}, \mathrm{P}$ and $\mathrm{N}$ followed by $\mathrm{Mg}$ and $\mathrm{Ca}$, at $60 \mathrm{DAS}$, if compared to other cover crops, explained by the higher $\mathrm{C} / \mathrm{N}$ ratio inherent to grasses, demonstrating this species accumulative potential (Table 3). However, values were higher than those found by Pacheco et al. (2011), who have worked with P. glaucum; Boer et al. (2007), with the ADR 300; Torres, Pereira, Andrioli, Polidoro \& Fabian et al. (2005), Torres \& Pereira (2008), with P. americanum sin typhoides. These results demonstrate that the dynamic of DB decomposition and nutrient releasing is significantly influenced by each season environmental conditions, what may be related to the quantity and time of precipitation onset, average temperatures, in addition to mesofauna and soil microbes.

\section{Conclusion}

The Pennisetum glaucum has stood out as for biomass production and accumulation of macronutrients (N, K, P, $\mathrm{Ca}$ and $\mathrm{Mg}$ ) in the early off- season crop.

B. ruziziensis and the consortium B. ruziziensis + Cajanus cajan have shown a high amount of biomass and nutrient accumulation in the end of the off-season crop.

The highest $\mathrm{C} / \mathrm{N}$ ratios were found in Pennisetum glaucum.

The nutrient with the highest release rate in soil was calcium.

\section{Acknowledgements}

We would like to thank the AGRISUS Foundation and COMIGO Cooperative, for the financial support, and CAPES, for the PhD scholarship concession. Also, Professor Maraisa Lopes, for the English Grammar review.

\section{References}

Aita, C., \& Giacomini, J. (2003). Decomposição e liberação de nitrogênio de resíduos culturais de plantas de cobertura do solo solteiras e consorciadas. Revista Brasileira de Ciência do solo, 27, 601-612. 
http://dx.doi.org/10.1590/S010006832003000400004

Amabile, R. F., Fancelli, A. L., \& Carvalho, A. M. (2000). Comportamento de espécies de adubos verdes em diferentes épocas de semeadura e espaçamentos na região dos cerrados. Pesquisa Agropecuária Brasileira, 35, 47-54. http://dx.doi.org/10.1590/S0100-204X2000000100007

Araújo, W. F., Sampaio, R. A., \& Medeiros, R. D. (2005). Resposta de cultivares de soja à adubação fosfatada. Revista Ciência Agronômica, 36, 129-134.

Bertin, E. G., Andrioli, I., \& Centurion, J. F. (2005). Plantas de cobertura em pré-safra ao milho em plantio direto. Acta Scientiarum, Londrina, 27, 379-386.

Boer, C. A., Assisi, R. L., Silva, G. P., Braz, A. J. B. P., Barroso, A. L. L., Cargnelutti Son, A., \& Pires, F. R. (2007). Ciclagem de nutrientes por plantas de cobertura na entressafra em um solo de cerrado. Pesquisa Agropecuária Brasileira, 42, 1269-1276. http://dx.doi.org/10.1590/S0100-204X2007000900008

Braz, A. J. B. P., Silveira, P. M., Kliemann, H. J., \& Zimmermann, F. J. P. (2004). Acumulação de nutrientes em folhas de milheto e dos capins braquiária e mombaça. Pesquisa Agropecuária Tropical, 34, 83-87.

Cantarella, H., Quaggio, H. C., \& Raij, B. V. (2001). Determinação da Matéria Orgânica. In Raij, B.V.; Andrad, J. C.; Cantarella, H.; Quaggio, J. A. ed. Análise Química para Avaliação da Fertilidade de Solos Tropicais. 1. ed. Campinas: Instituto Agronômico de Campinas, 173-188.

Carpim, L., Assisi, R. L., Braz, A. J. B. P., Silva, G. P., Pires, F. R., Pereira, V. C., ... Silva, A. G. (2008). Liberação de nutrientes pela palhada de milheto em diferentes estádios fenológicos. Revista Brasileira de Ciência do Solo, 32, 2813-2819.http://dx.doi.org/10.1590/S0100-06832008000700027

Conab. (2012). Companhia Nacional de Abastecimento. $6^{\circ}$ Levantamento da Produção de Grãos - Safra 2011/12. Brasília: Conab, 2012. Disponível em: $<$ http://www.conab.gov.br>. Acesso em: 07 de mar. 2012.

Crusciol, C. A. C., Cottica, R. L., Lima, E. V., Andreotti, M., Moro, E., \& Marcon, E. (2005). Persistência de palhada e liberação de nutrientes do nabo forrageiro no plantio direto. Pesquisa Agropecuária Brasileira, 40, 161-168. http://dx.doi.org/10.1590/S0100-204X2005000200009

Crusciol, C. A. C., \& Soratto, R. P. (2009). Nitrogen supply for cover crops and effects on peanut grown in succession under a no-till system. Journal Agronomy, Madison, 101, 41-46.

Embrapa, Centro Nacional de Pesquisa de Solos. (1999). Sistema Brasileiro de Classificação de Solos. Brasília: Embrapa Produção da Informação; Rio de Janeiro: Embrapa Solos.

Fabian, A. J. (2009). Plantas de cobertura: efeito nos atributos do solo e na produtividade de milho e soja em rotação. Tese de Doutorado, Curso de Pós-Graduação em Produção Vegetal, Universidade Estadual Paulista, Jaboticabal-SP.

Gama-Rodrigues, A. C., Gama-Rodrigues, E. F., \& Brito E. C. (2007). Decomposição e liberação de nutrientes de resíduos culturais de plantas de cobertura em Argissolo Vermelho-Amarelo na região Noroeste Fluminense (RJ). Revista Brasileira de Ciência do Solo, 31, 421-1428. http://dx.doi.org/10.1590/S0100-06832007000600019

Giancotti, P. R. F., Neponuceno, M., Yamauti, M. S., Colmanetti M. A., Guzzo, C. D., \& Alves, P. L. C. A. (2010). Épocas de manejo de B. ruziziensis antecedendo o plantio direto do girassol (Resumo). XXVII Congresso Brasileiro da Ciência das Plantas Daninhas 19 a 23 de julho de 2010 - Centro de Convenções Ribeirão Preto - SP.

Henriksen, I., Michelsen, A., \& Schlonvoigt, A. (2002). Tree species selection and soil tillage in alley cropping systems with Phaseolus vulgaris L. in a humid premontane climate: biomass production, nutrient cycling and crop responses. Plant and Soil, 240, 145-159.

Lara Cabezas, W. R. L., Alves, B. J. R., Urquiaga, S., \& Santana, D. G. (2004). Influência da cultura antecessora e da adubação nitrogenada na produtividade de milho em sistema plantio direto e solo preparado. Ciência Rural, 34, 1005- 1013. http://dx.doi.org/10.1590/S0103-84782004000400006

Menezes, L. A. S., \& Leandro, W. M. (2004). Avaliação de espécies de coberturas do solo com potencial de uso em sistema de plantio direto. Pesquisa Agropecuária Tropical, 34, 173-180.

Menezes, L. A. S., Leandro, W. M., Oliveira Junior, J. P., Ferreira, A. C. B., Santana, J. G., \& Barros, R. G. (2009). Produção de fitomassa de diferentes espécies, isoladas e consorciadas, com potencial de utilização para cobertura do solo. Biosci Journal, Uberlândia, 25, 7-12. 
Nogueira, A. R. de A., Matos, A. de O., Carmo, C. A. F. de S. do., Silva, D. J., Monteiro, F. L., Souza, G. B. de., ... Oliveira Neto, W. de. Tecido vegetal. In: Nogueira, A. R. de A., Souza, G. B. de (Ed). (2005). Manual de laboratórios: solo, água, nutrição vegetal, nutrição animal e alimentos. São Carlos: Embrapa Pecuária Sudoeste, 145-199.

Nunes, U. R., Andrade Junior, V. C. A., Silva, E. B., Santos, N. F., Costa, H. A. O., \& Ferreira, C. A. (2006). Produção de palhada de plantas de cobertura e rendimento do feijão em plantio direto. Pesquisa Agropecuária Brasileira, 41, 943-948. http://dx.doi.org/10.1590/S0100-204X2006000600007

Pacheco, L. P., Pires, F. R., Monteiro, F. P., Procopio, S. O., Assis, R. L., Carmo, M. L., \& Petter, F. A. (2008). Desempenho de plantas de cobertura em sobressemeadura na cultura da soja. Pesquisa Agropecuária Brasileira, 43, 815-823. http://dx.doi.org/10.1590/S0100-204X2008000700005

Pacheco, L. P., Leandro, W. M., Machado, P. L. O. A., Assis, R. L., Cobucci, P., Madari, B. E., \& Petter, F. A. (2011). Produção de fitomassa e acúmulo e liberação de nutrientes por plantas de cobertura na safrinha. $\begin{array}{lllll}\text { Pesquisa agropecuária } & \text { brasileira, } & \text { Brasilia, } & 46, & \text { 17-25. }\end{array}$ http://dx.doi.org/10.1590/S0100-204X2011000100003

Paul, E. A., \& Clark, F. E. (1989). Soil chemistry and microbiology. 1. and d. San Diego: Academic Press, p. 275.

Perin, A., Santos, R. H. S., Urquiaga, S. C., Guerra, J. G. M., \& Cecon, P. R. (2004). Produção de fitomassa, acúmulo de nutrientes e fixação biológica de nitrogênio por adubos verdes em cultivo isolado e consorciado. Pesquisa Agropecuária Brasileira, 39, 35-40. http://dx.doi.org/10.1590/S0100-204X2004000100005

Pires, F. R., Assis, R. L., Procópio, S. O., Silva, G. P., Moraes, L. L., Rudovalho, M. C., \& Boer, C. A. (2008). Manejo de plantas de cobertura antecessoras à cultura da soja em plantio direto. Revista Ceres, Viçosa, 094-101.

Prior, S. A., Torbert, H. A., Runion, G. B., \& Rogers, H. (2004). Elevated atmospheric $\mathrm{CO}_{2}$ in agroecosystems: residue decomposition in the field. Environmental Management, 33, 344-354.

Sodré Filho, L., Cardoso, A. N., Carmoral, R., \& Carvalho, A. M. (2004). Fitomassa e cobertura do solo de culturas de sucessão ao milho na Região do Cerrado. Pesquisa Agropecuária Brasileira, 39, 327-334.

Torres, J. L. R., Pereira, M. G., Andrioli, I., Polidoro, J. C., \& Fabian, A. J. (2005). Decomposição e liberação de nitrogênio de resíduos culturais de plantas de cobertura em um solo de cerrado. Revista Brasileira de Ciência do Solo, 29, 609-618. http://dx.doi.org/10.1590/S0100-06832005000400013

Torres, J. L. R., \& Pereira, M. G. (2008). Dinâmica do potássio nos resíduos vegetais de plantas de cobertura no cerrado. Revista Brasileira de Ciência do Solo, 32, 1609-1618. http://dx.doi.org/10.1590/S0100-06832008000400025

Wieder, R. K., \& Lang, G. E. (1982). A critique of the analytical methods used in examining decomposition data obtained from litter bags. Ecology, 63, 1636-1642. 